\title{
Persepsi Auditor atas Konflik Kepentingan dan Perburuan Rente dalam Mendeteksi Indikasi Fraud
}

\author{
Natasha Priscilla Silooy ${ }^{1 *}$, Novita ${ }^{2}$ \\ 1, 2 Universitas Trilogi \\ 1natasha.priscilla19@gmail.com; ${ }^{2}$ novita_1210@trilogi.ac.id \\ ${ }^{*}$ Penulis korespondensi
}

\begin{abstract}
This study aims to prove that conflict of interest and rent seeking have a positive effect on indications of fraud based on the auditor's perception. Indications of fraud in this study using the theory of fraud pentagon which consists of pressure, rationalization, opportunity, capability, and arrogance. Furthermore, conflicts of interest are seen from personal, relational, cultural, and structural indicators. While the indicators of rent seeking are seen from working capital, debt, corporate immunity, creative accounting, and corporate governance. This research is quantitative research using primary data. The population in this study are auditors who work in public accounting firms. The research sample consisted of 100 samples and was obtained using non-probability sampling and incidental sampling methods. The data analysis technique used the Partial Least Square method which consisted of descriptive and verification analysis. The results of the study show that conflicts of interest and rent seeking have a positive and significant effect on indications of fraud. The results of this study support the fraud pentagon theory that conflict-of-interest activities and rent seeking have an influence on indications of fraud.
\end{abstract}

Keywords: conflict of interest, rent seeking, indication of fraud, fraud pentagon

\begin{abstract}
Abstrak
Penelitian ini bertujuan untuk membuktikan bahwa konflik kepentingan dan perburuan rente berpengaruh positif terhadap indikasi fraud berdasarkan persepsi auditor. Indikasi fraud dalam penelitian ini menggunakan teori fraud pentagon yang terdiri dari dorongan, rasionalisasi, kesempatan, kapabilitas, dan arogansi. Selanjutnya konflik kepentingan dilihat dari indikator personal, relasional, kultural, dan struktural. Sedangkan indikator perburuan rente dilihat dari modal kerja, hutang, imunitas perusahaan, creative accounting, dan tata kelola perusahaan. Penelitian ini merupakan penelitian kuantitatif dengan menggunakan data primer. Populasi dalam penelitian ini adalah Auditor yang bekerja di Kantor Akuntan Publik. Sampel penelitian sebanyak 100 sampel dan diperoleh menggunakan metode nonprobability sampling dan incidental sampling. Teknik analisis data menggunakan metode Partial Least Square yang terdiri dari analisis deskriptif dan verifikatif. Hasil penelitian menunjukan bahwa konflik kepentingan dan perburuan rente berpengaruh positif dan signifikan terhadap indikasi fraud. Hasil penelitian ini mendukung teori fraud pentagon bahwa kegiatan konflik kepentingan dan perburuan rente memiliki pengaruh terhadap indikasi fraud.
\end{abstract}

Kata Kunci: konflik kepentingan, perburuan rente, indikasi fraud, fraud pentagon 


\section{PENDAHULUAN}

Permasalahan kecurangan yang terjadi di Indonesia dapat terjadi baik pada perusahaan swasta maupun perusahaan milik negara bahkan tidak jarang melibatkan instansi pemerintah. Seperti kasus yang terjadi di PT. Garuda Indonesia dimana Komisi Pemberantasan Korupsi (KPK) menemukan bukti penerimaan suap dari perusahaan asing kepada mantan Direktur Utama PT. Garuda Indonesia dan dalam kasus ini ia terbukti melakukan kecurangan karena menerima suap sejumlah uang dari perusahaan asing atas kerjasamanya karena melakukan pembelian pesawat dan mesin pesawat (Rozie, 2019). Selanjutnya kasus indikasi kecurangan pada polis asuransi Jiwasraya yang dibuktikan dengan adanya kegiatan konflik kepentingan dan perburuan rente sehingga menyebabkan kerugian negara mencapai 37 Triliun dan berdampak pada gagal bayar kepada nasabahnya (Pratama, 2020). Kasus konflik kepentingan dan perburuan rente juga telah terjadi pada Kementerian Kelautan dan Perikanan (KKP) dengan ditemukannya praktik korupsi ekspor benih lobster. Indikasi kasus korupsi ini tidak hanya melibatkan Menteri Kelautan dan Perikanan saja namun melibatkan beberapa pejabat KKP dan sejumlah orang yang memiliki kepentingan bersama. Tim penasehat dalam Kementerian Kelautan dan Perikanan memaparkan perkiraan kerugian negara akibat sindikat bisnis illegal ekspor benur yang mencapai Rp. 10,08 triliun (Liputan 6, 2020). Indikasi kecurangan yang disebabkan oleh perburuan rente juga terjadi pada Kementerian Sosial yaitu dalam hal bantuan sosial Covid-19. Kegiatan perburuan rente dilakukan dengan cara mengambil rente sebesar Rp 10.000 dari tiap paket sembako bantuan sosial untuk warga miskin yang bernilai Rp. 300.000 per paket sembako (Detik News, 2020).

Fraud merupakan suatu tindakan penyalahgunaan wewenang dan tanggung jawab di dalam suatu entitas. Teori fraud pentagon yang dicetuskan oleh Crowe Horwart merupakan perluasan dari teori fraud triangle dan fraud diamond memiliki lima elemen yaitu pressure, rationalization, opportunity, competence, dan arrogance. Pressure merupakan pendorong seseorang melakukan kecurangan umumnya disebabkan oleh faktor ekonomi seperti terlibat utang dan memiliki gaya hidup lebih tinggi dari pendapatan. Ketika seseorang mendapat tekanan maka sering terjadi rationalization atau pembenaran atas suatu tindakan yang dilakukan yang mengarah pada sebuah kecurangan. Kecurangan juga dapat terjadi ketika adanya opportunity diantaranya ketika ada kelemahan dalam pengendalian internal pada suatu aktivitas. Selanjutnya apabila seseorang memiliki kompetensi yang tinggi ditambah dengan posisi jabatan yang juga tinggi maka cenderung akan menyebabkan management override dan mengesampingkan internal kontrol atau mengontrol suatu kebijakan atau kegiatan sesuai dengan kedudukan yang dimiliki untuk kepentingan pribadi. Superioritas atau arogansi yang dalam diri pelaku yang menganggap bahwa kebijakan dan prosedur perusahaan tidak berlaku untuk dirinya (Alfina \& Amrizal, 2020).

Kasus fraud yang umumnya terjadi pada suatu entitas dikarenakan adanya benturan kepentingan antara pihak prinsipal dan pihak agen. Di dalam teori keagenan pihak prinsipal merupakan pihak pemegang saham yang dimana ia memiliki hubungan kerjasama dengan pihak agen (Wahyuni, 2019). Pihak agen merupakan pihak manajemen yang telah disewa untuk melakukan suatu jasa dan pihak prinsipal memberikan wewenang pada pihak agen dalam pengambilan suatu keputusan. Menurut (Supriyono, 2018) hubungan ini dijalankan 
untuk menghasilkan sebuah jasa dan pihak agen harus membuat atau mengambil sebuah keputusan yang terbaik bagi pihak prinsipal dengan mengutamakan kepentingan dan mengoptimalkan laba perusahaan sehingga pihak agen dapat meminimalisir beban. Dalam hal ini pihak prinsipal selalu menginginkan pengembalian yang tinggi atas investasi yang dikeluarkan untuk perusahaan, sedangkan pihak agen memiliki kepentingan tersendiri yaitu untuk mendapatkan kompensasi atau hasil yang lebih besar atas kinerjanya (Wongso, 2012).

Konflik kepentingan (conflict of interest) dapat terjadi ketika seseorang mengambil sebuah ketetapan penjualan, ketetapan pembelian, ketetapan operasional, ketetapan keuangan, ketetapan hukum dan atau ketetapan kebijakan dalam nama bentuk apapun tidak memihak kepada nilai kebenaran, kejujuran, dan keadilan (Priantara, 2016). Konflik kepentingan yang terjadi dalam entitas secara terus menerus akan menjadi sebuah pelegalan dalam pengambilan keputusan yang berdasarkan keinginan pribadi dan apabila hal tersebut tidak dicegah maka dapat menumbuhkan perilaku koruptif yang menyebabkan pembiaran praktik pengelolaan entitas yang tidak sehat, tidak terbuka, dan hanya dipenuhi oleh rasa curiga.

Indikator konflik kepentingan dapat dilihat dari nilai-nilai yang bersifat personal yang menyangkut karakteristik individu, kepribadian, emosional dan spiritual. Pendekatan relasional juga menjadi hal yang dapat menyebabkan konflik kepentingan terutama dalam pengambilan keputusan. Entitas harus selalu menguji pola hubungan, pola komunikasi, gaya kepemimpinan dan manajemen dalam pengelolaan situasi konflik yang melibatkan berbagai kelompok pemangku kepentingan. Selanjutnya konflik kepentingan dilihat dari desain struktur entitas dikarenakan sangat penting untuk memastikan efisiensi dan efektivitas kinerja entitas. Terakhir, nilai-nilai kultur yang terdapat dalam lingkungan juga akan mempengaruhi bagaimana entitas melakukan kegiatan operasinya (Sulistiyana \& Seran, 2016).

Indikasi kecurangan juga dapat disebabkan oleh praktik perburuan rente. Teori mengenai perburuan rente dikembangkan oleh Gordon Tullock dan kemudian diperkenalkan secara luas oleh Annna Krueger (Shughart, Razzolini, \& Reksulak, 2013) yang menjelaskan tentang perilaku pemangku kepentingan dalam seuah entitas yang berusaha untuk untuk memeperoleh sebuah perlakuan istimewa dari pihak yang berwenang seperti pemerintah. Hal menimbulkan sebuah perlakuan khusus seperti keringanan regulasi, pajak, aturan, peraturan, dan lain-lain. Perburuan rente menurut Rachbini dalam (Hermanto, 2020) adalah sebuah keadaan dimana seorang pengusaha atau perusahaan mengambil manfaat atau nilai yang tidak dikompensasikan dari yang lain lalu melakukan manipulasi pada lingkungan usaha atau bisnis. Perburuan rente pada lingkungan bisnis terjadi karena perebutan monopoli atas aturan main atau regulasi. Pelaku usaha melakukan kegiatan melobi penguasa untuk dapat lebih memihak kepada dirinya. Adapun penetapan tarif yang dilakukan oleh penguasa untuk kelompok bisnis tertentu juga merupakan bagian dari praktik perburuan rente. Praktik perburuan rente melibatkan pihak-pihak pengusaha, pemilik modal, dan penguasa, karena dari komponen inilah praktik perburuan rente dapat berjalan. Istilah praktik perburuan rente di Indonesia memang masih asing terdengar oleh masyarakat secara umum. Namun pada kenyataannya praktik ini sudah berlangsung lama di Indonesia. Pada era Orde Lama perburuan rente terjadi ketika pemerintah memudahkan izin dan kredit impor bagi pengusaha pribumi agar dunia bisnis pribumi berkembang. Namun pengusaha pribumi menjual haknya kepada pengusaha asing. 
Menurut (Mahsun, 2020) indikasi praktik perburuan rente pada entitas dapat dilihat dari working capital rendah, hutang yang tinggi, creative accounting, imunitas rendah, good governance semu. Working capital rendah adalah sebuah keadaan dimana sebuah entitas yang memiliki modal kerja yang minim namun mampu memiliki proyek yang besar. Dimana entitas tersebut mendanai proyeknya dengan kekuatan hutang. Entitas yang melakukan praktik perburuan rente biasanya melakukan make up laporan keuangan sehingga sesuai dengan standar akuntansi. Entitas yang melakukan praktik perburuan rente mudah bertumbangan saat menghadapi krisis ekonomi dan menyalahkan krisis akibat kinerja buruknya hal itu dikarenakan entitas yang melakukan kegiatan perburuan rente tidak memiliki tata kelola perusahaan yang baik atau hanya memiliki tata kelola yang digunakan sebagai formalitas perusahaan saja.

Konflik kepentingan yang terjadi secara terus-menerus dapat menyebabkan fraud di dalam entitas karena kegiatan ini hanya memberi keuntungan kepada orang-orang yang memiliki kesamaan kepentingan. (Oktaviani, Herawati, \& Atmadja, 2017) mengatakan bahwa konflik kepentingan berpengaruh positif terhadap potensi fraud dalam pengelolaan keuangan desa, konflik kepentingan yang dimaksud dalam situasi tersebut adalah ketika seorang yang memiliki wewenang diduga memiliki kepentingan pribadi sehingga mempengaruhi kinerjanya dan berujung pada fraud. Pada penelitian yang dilakukan oleh (Suryandari \& Priyanto, 2012) dijelaskan bahwa semakin tinggi tingkat konflik kepentingan yang terjadi pada suatu perusahaan maka semakin tinggi diterapkannya konservatisme akuntansi dan di dalam penelitian (Zulfa, 2017) dikemukakan bahwa konflik kepentingan memiliki pengaruh positif terhadap konservatisme akuntansi hal ini biasanya disebabkan oleh terjadinya kebijakan dimana investor memilih dan mengatur manajer dalam mentransfer keuntungan dari kekayaan kreditor dan hal ini yang dapat menyebabkan kecurangan terjadi. (Septiningrum, 2017) mengemukakan bahwa konflik kepentingan berpengaruh positif terhadap kesenjangan anggaran dalam penyusunan anggaran partisipatif, penelitian ini selaras dengan teori agensi yang menyebutkan terdapatnya perbedaan kepentingan antara manajer atas dan manajer bawah sehingga menimbulkan kecurangan yang dilakukan oleh satu pihak kepada pihak lain. Dijelaskan oleh (Saputra, Ni, \& Jayawarsa, 2019) bahwa konflik kepentingan memiliki pengaruh positif terhadap independensi auditor dimana konflik kepentingan tidak selalu memberi kerugian secara langsung namun setelah konflik kepentingan tersebut terjadi maka akan ada kerugian yang ditimbulkan, konflik kepentingan juga dilokalisir sebagai perbuatan tidak etis. Sejalan dengan penelitian yang dilakukan oleh (Hermawan \& Novita, 2021) dijelaskan bahwa tata kelola perusahaan memiliki pengaruh positif pada upaya untuk meminimalisirkan indikasi kecurangan yang salah satunya merupakan konflik kepentingan.

Perburuan rente diyakini menjadi salah satu penyebab terjadinya indikasi kecurangan pada entitas. Penelitian (Nugraha, 2018) menjelaskan bahwa terjadinya kegiatan perburuan rente yang dilakukan antara penyelenggara dengan penyedia dan berujung korupsi (penyuapan, penggelembungan dana, penggelapan anggaran, penyalahgunaan wewenang, dan sebagainya). Penelitian ini juga selaras dengan hasil penelitian yang dilakukan oleh (Nugroho, 2018) yang di dalam penelitiannya menyatakan banyaknya fenomena aktivitas ekonomi perburuan rente dan korupsi. Penelitian (Liu, Lin, Chan, \& Fung, 2018) menyatakan bahwa terdapat pengaruh positif dan signifikan antara pemburu rente dan manajemen laba yang dimana perburuan 
rente mempengaruhi manajemen laba. (Lee, Ning, Hsieh, \& Lee, 2020) menunjukkan hasil bahwa perusahaan yang terdaftar lebih cenderung melakukan aktivitas perburuan rente daripada perusahaan yang tidak terdaftar, penelitian ini juga melengkapi tentang pengaruh positif koneksi politik terhadap kinerja swasta atau pemburu rente. (Mahpudin \& Aziz, 2021) mengemukakan bahwa perburuan rente tidak selalu berkaitan dengan mencari keuntungan materi namun bisa dalam bentuk politik balas budi dan memanipulasi kebijakan yang dapat menguntungkan para pemangku kepentingan. Dalam saat yang bersamaan perusahaan mendapatkan keuntungan dari kebijakan yang dibuat oleh elit politik dengan cara menyuap dan cara lain yang melanggar konstitusi.

Keterbaruan penelitian ini dengan penelitian terdahulunya adalah menguji keterkaitan inidikasi fraud dengan konflik kepentingan dan kegiatan perburuan rente yang dilihat dari persepsi auditor. Output dari penelitian ini dapat menjadi himbauan agar masyarakat lebih mengenal dan menyadari akan hadirnya konflik kepentingan dan kegiatan perburuan rente disekitarnya. Bagi perkembangan ilmu akuntansi khususnya audit forensik, penelitian ini diharapkan dapat memberikan kontribusi agar lebih banyak yang menyadari akan berbagai macam kecurangan. Penelitian ini juga diharapkan dapat memberikan kontribusi bagi entitas serta pemerintah dalam mendeteksi indikasi fraud. Selanjutnya hipotesis penelitian yang dibentuk pada penelitian ini adalah:

\section{$\mathrm{H}_{\mathbf{1}}$ : Terdapat pengaruh positif antara Konflik Kepentingan terhadap Indikasi Fraud $\mathrm{H}_{2}$ : Terdapat pengaruh positif antara Perburuan Rente terhadap Indikasi Fraud}

\section{METODE}

Penelitian ini dilakukan terhadap Auditor yang bekerja di Kantor Akuntan Publik (KAP), penelitian ini dilakukan pada tahun 2021. Penelitian ini menjadikan auditor yang bekerja di Kantor Akuntan Publik (KAP) sebagai objek penelitian dikarenakan auditor diharapkan memiliki sikap umum yang tertulis di Standar Profesional Akuntan Publik (SPAP) yang memiliki keahlian dan pelatihan teknis, independensi, dan profesionalisme dalam penggunaan kemahiran profesional auditor dengan cermat dan seksama. Data penelitian merupakan data primer yang diperoleh melalui kuesioner atau angket dengan menggunakan google form. Penelitian ini menggunakan metode nonprobability sampling karena jumlah populasi dari auditor yang bekerja di Kantor Akuntan Publik (KAP) tidak diketahui jumlahnya dan penelitian ini juga menggunakan metode incidental sampling yang merupakan teknik penentuan sampel berdasarkan kebetulan, yaitu responden yang secara kebetulan bertemu dengan peneliti dan orang yang kebetulan ditemui itu cocok sebagai sumber data atau sesuai dengan kriteria penelitian.

Variabel dengan instrumen skala penilaian pada skala 1 sampai dengan 4. Responden diminta memberikan nilai dari pernyataan dari skala 1 "sangat tidak setuju" sampai 4 "sangat setuju". Instrumen yang digunakan untuk mengukur variabel penelitian ini dengan menggunakan Rating Scale yaitu alat pengumpulan data yang berupa daftar yang berisi ciri-ciri setuju atau tidak setuju yang harus dicatat secara bertingkat (Sugiyono, 2016).

Dalam penelitian ini jumlah populasi tidak diketahui, maka untuk memudahkan penentuan jumlah sampel yang diambil ditentukan dengan rumus (Akdon \& Riduwan, 2013): 


$$
\begin{aligned}
n & =\frac{(\mathrm{Za} / 2 \sigma)^{2}}{\varepsilon} \\
n & =\frac{(1,96) \cdot(0,25)^{2}}{0,05} \\
& =96,04
\end{aligned}
$$

Keterangan:

$n \quad=$ Jumlah sampel

$\mathrm{Z}_{\mathrm{a} / 2}=$ Nilai yang didapat dari table normal atas tingkat keyakinan

$\sigma \quad=$ Standar devisiasi populasi

$\varepsilon \quad=$ Estimasi error yang digunakan

Dari hasil penyebaran kuisioner melalui gform selama periode Oktober 2020 sampai dengan April 2021 telah diperoleh 116 sampel dan setelah disesuaikan dengan kriteria sampel maka diperoleh sampel penelitian untuk dianalisis lebih lanjut adalah sebanyak 100 sampel. Metode analisis data dalam penelitian ini menggunakan analisis deskriptif dan verikatif. Analisis deskriptif digunakan untuk menganalisis terjadinya konflik kepentingan dan perburuan rente terhadap indikasi fraud. Analisis verifikatif digunakan untuk menguji dan mencari kebenaran dari hipotesis yang diajukan. Pengujian hipotesis dalam penelitian ini menggunakan metode Partial Least Square (PLS). Metode Partial Least Square (PLS) adalah sebuah model analisis yang powerful dan disebut soft modeling karena tidak dengan dasar pada asumsi dan syarat, seperti uji normalitas dan multikolinearitas (Ghozali \& Latan, 2015). Metode Partial Least Square (PLS) untuk menguji teori lemah dan data yang lemah serta jumlah sampel yang sedikit dan masalah normalitas data.

\section{HASIL DAN PEMBAHASAN}

\section{Uji Deskriptif}

Berikut ini adalah gambaran hasil uji deskriptif yang dilakukan:

\section{Gambar 1. Hasil analisis deskriptif variabel Konflik Kepentingan}

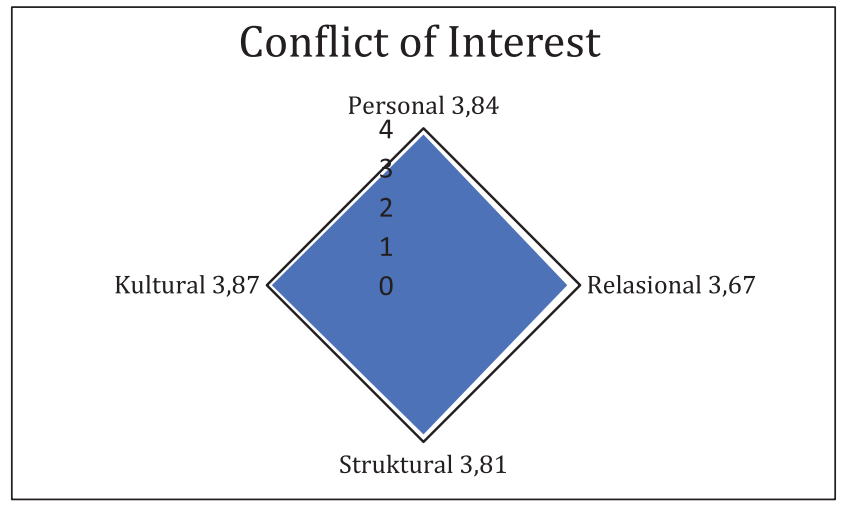

Sumber: Kuesioner, diolah, 2021

Berdasarkan hasil pada gambar 1 menunjukan bahwa responden setuju pada nilai di atas 3,0. Responden yang terdiri dari para auditor menyatakan setuju bahwa konflik kepentingan 
dipengaruhi oleh personal, relasional, struktural, dan kultural. Personal dipengaruhi oleh karakteristik individu, kepribadian, dan emosional. Responden menyetujui bahwa konflik kepentingan terjadi karena keinginan individu itu sendiri maka dari itu untuk meminimalisir konflik kepentingan dalam suatu entitas maka perlu adanya proses penilaian kinerja guna untuk mengetahui jejak rekam dari seseorang yang akan mengisi posisi penting di dalam entitas, perusahaan juga wajib melakukan psikotest untuk calon karyawan, memberi pelatihan pengembangan emosional dan spiritual untuk karyawan guna memotivasi karyawan dan meningkatkan potensi yang dimilikinya. Relasional dipengaruhi oleh hubungan relasional antar individu, antar kelompok, antar pemangku kepentingan, antar keyakinan, dan sebagainya yang dimana sering ditemukan terdapatnya hubungan istimewa antara manajemen dan vendor, terdapatnya kegiatan nepotisme di dalam suatu entitas. Struktural dipengaruhi oleh struktur entitas yang dalam hal ini mengatur tentang kode etik dan perilaku bisnis seperti pelarangan menerima pemberian gratis, memiliki auditor internal guna memberi pendapat objektif, dan mencegah kepemimpinan yang management override. Kultural dipengaruhi oleh nilai-nilai kultur yang terdapat di dalam suatu entitas seperti memberi pengaruh dalam pelaksanaan kegiatan operasinya seperti terdapatnya sebuah sistem whistleblowing di dalam perusahaannya, mengadakan seminar berkala mengenai anti fraud guna mencegah, dan menyadari segala bentuk konflik kepentingan yang akan berujung pada fraud.

\section{Gambar 2. Hasil analisis deskriptif variabel Perburuan Rente}

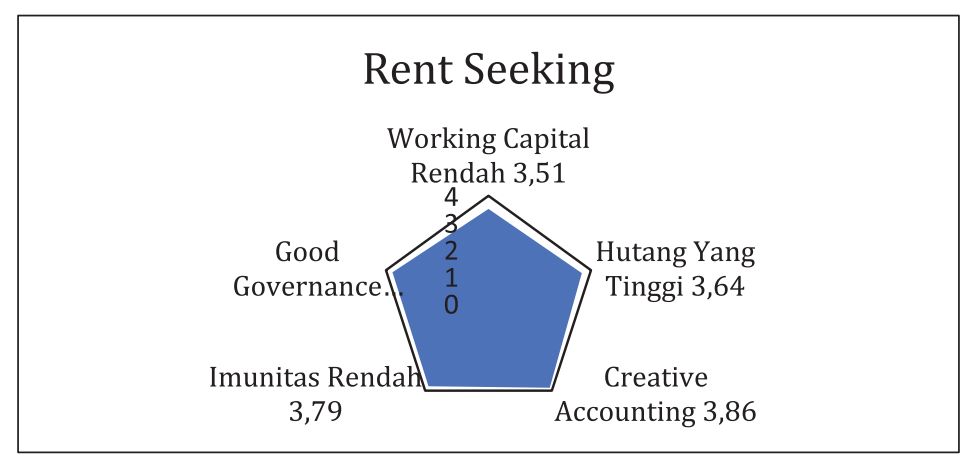

Sumber: Kuesioner, diolah, 2021

Berdasarkan hasil pada gambar 2 menunjukan bahwa responden setuju pada nilai di atas 3,0. Responden yang terdiri dari para auditor menyatakan setuju bahwa perburuan rente dipengaruhi oleh working capital rendah, hutang yang tinggi, creative accounting, imunitas rendah, good governance semu. Working capital rendah adalah sebuah keadaan dimana sebuah entitas yang memiliki modal kerja dan pengalaman yang minim namun mampu memiliki proyek yang besar. Dimana entitas tersebut mendanai proyeknya dengan kekuatan hutang. Entitas yang melakukan praktik perburuan rente biasanya melakukan make up laporan keuangan sehingga sesuai dengan standar akuntansi maupun regulasi tertentu guna meyakinkan pemangku kepentingan. Entitas yang melakukan praktik perburuan rente mudah bertumbangan saat menghadapi krisis ekonomi dan menyalahkan krisis akibat kinerja buruknya hal itu dikarenakan entitas yang melakukan kegiatan perburuan rente tidak memiliki tata kelola perusahaan yang baik atau hanya memiliki tata kelola yang digunakan sebagai formalitas sebuah perusahaan saja. 
Berdasarkan hasil pada gambar 3 menunjukan bahwa responden setuju pada nilai di atas 3,0. Responden yang terdiri dari para auditor menyatakan setuju bahwa fraud terjadi karena terdapatnya dorongan, rasionalisasi, kesempatan, kapabilitas, dan arogansi. Dorongan dimaksudkan dengan banyaknya hutang atau tagihan yang dimiliki oleh pelaku, lifestyle, dan sifat serakah yang menyebabkan fraud terjadi. Rasionalisasi adalah sebagai sebuah tindakan mencari alasan atau pembenaran oleh orang-orang yang merasa dirinya terjebak dalam suatu keadaan yang buruk dan pelaku akan mencari alasan untuk membenarkan kejahatan yang sudah dilakukannya agar tindakan tersebut dapat diterima dan dimaafkan oleh masyarakat. Kesempatan ialah momen ketika pelaku dipengaruhi oleh situasi sehingga pelaku memiliki peluang untuk melakukan kecurangan hal ini disebabkan oleh pengawasan yang kurang dan penyalahgunaan wewenang. Kapabilitas atau kompetensi adalah sifat dan kemampuan seseorang yang mempunyai peranan besar di dalam sebuah entitas memungkinkan orang tersebut melakukan suatu tindak kecurangan dimana pelaku memiliki sebuah kemampuan untuk mengesampingkan internal kontrol dan mengontrolnya sesuai dengan kedudukan sosialnya untuk kepentingan pribadinya. Lalu arogansi dimana seseorang memiliki sikap superioritas dan keserakahan dalam sebagian dirinya yang menganggap bahwa kebijakan dan prosedur perusahaan tidak berlaku untuknya.

Gambar 3. Hasil analisis deskriptif variabel Fraud

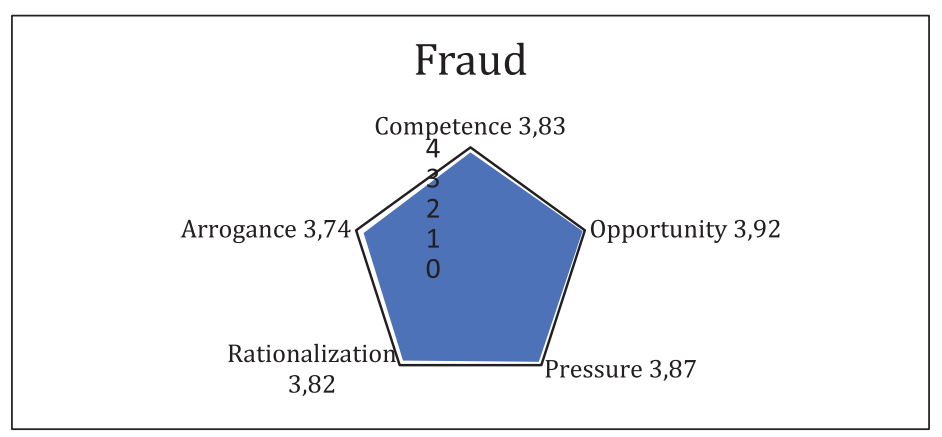

Sumber: Kuesioner, diolah, 2021

Tahapan berikutnya melakukan analisis verifikatif dengan pengujian keabsahan serta keandalan dari data. Data yang sah dan andal adalah data yang memiliki nilai loading faktor di atas 0,70. Dibutuhkan modifikasi terhadap model struktural agar menghasilkan nilai outer loading di atas 0,70. Dalam analisis validitas untuk variabel konflik kepentingan, perburuan rente, dan fraud terdapat beberapa indikator yang tidak sesuai harapan sehingga total keseluruhan dari 43 indikator hanya 27 indikator yang memiliki nilai validitas yang baik.

\section{Uji Verifikatif}

Tabel 1 menunjukkan data setiap variabel dengan nilai sama atau lebih dari 0,60. Hasil ini membuktikan bahwa terdapat hubungan baik antara setiap variabel antara setiap indikator. Selain itu setiap variabel memiliki nilai validitas yang sangat baik dalam setiap perhitungannya. 
Tabel 1 Average Variance Extracted (AVE)

\begin{tabular}{lc}
\hline & Average Variance Extracted (AVE) \\
\hline X1 (Conflict of Interest) & 0.730 \\
X2 (Rent Seeking) & 0.704 \\
Y (Fraud) & 0.696 \\
\hline
\end{tabular}

Sumber: Kuesioner, diolah, 2021

Tabel 2 menunjukkan nilai composite reliability lebih dari 0,70 sehingga membuktikan bahwa composite reliability menunjukan nilai realibilitas yang baik. Dari hasil pengujian maka penelitian ini dapat dikatakan tepat dan terpercaya, karena memiliki hasil atau nilai yang konsisten. Yang dimana apabila dilakukan pengujian kembali pada penelitian ini maka hasil yang diharapkan dapat memiliki nilai yang sama untuk konflik kepentingan terhadap fraud, dan perburuan rente terhadap fraud.

Tabel 2 Hasil Uji Reabilitas

\begin{tabular}{lcc}
\hline & Cronbach's Alpha & Composite Realibility \\
\hline X1 (Conflict of Interest) & 0.876 & 0.915 \\
X2 (Rent Seeking) & 0.947 & 0.955 \\
Y (Fraud) & 0.926 & 0.941 \\
\hline
\end{tabular}

Sumber: Kuesioner, diolah, 2021

Tabel 3 menunjukkan nilai path coefficient lebih dari 0 sehingga membuktikan bahwa hubungan konflik kepentingan terhadap fraud memiliki pengaruh positif dan hubungan perburuan rente terhadap fraud memilik pengaruh positif.

Tabel 3 Nilai Path Coefficient

\begin{tabular}{cc}
\hline & Y (Fraud) \\
\hline X1 (Conflict of Interest) & 0.382 \\
X2 (Rent Seeking) & 0.457 \\
\hline
\end{tabular}

Sumber: Kuesioner, diolah, 2021

Tabel 4 menunjukkan R Square sebesar 0,615 sehingga memiliki hubungan moderat, yang artinya 61,5\% variabel fraud dipengaruhi oleh konflik kepentingan dan perburuan rente sedangkan 38,5\% merupakan hasil variabel yang berada di luar penelitian ini yang sedang tidak dipergunakan atau diuji. Hasil ini juga diperkuat oleh hasil R Square Adjusted yang memiliki nilai tidak jauh berbeda yaitu sebesar 0,607 dengan menyatakan hubungan yang lebih menyeluruh antara indikator yang ada di dalamnya.

Tabel 4 Nilai R Square

\begin{tabular}{lcc}
\hline & R Square & R Square Adjusted \\
\hline Y (Fraud) & 0.615 & 0.607 \\
\hline
\end{tabular}

Sumber: Kuesioner, diolah, 2021 
Pengujian inner model dilakukan untuk melihat kapabilitas dari prediksi dengan menggunakan prosedur blindfolding dengan kriteria predictive relevance adalah 0,02 dikatakan lemah, 0,15 dikatakan moderat, dan 0,35 dikatakan kuat. Table 5 menunjukkan bahwa hasil dari predictive relevance sebesar 0.402 yang berarti variabel konflik kepentingan dan perburuan rente memiliki prediktif yang kuat terhadap variabel fraud.

Tabel 5 Nilai Blindfolding Calculation

\begin{tabular}{lc}
\hline \multicolumn{1}{c}{ Variabel } & Blindfolding Calculation \\
\hline X1 (Conflict of Interest) & 0.000 \\
X2 (Rent Seeking) & 0.000 \\
Y (Fraud) & 0.402 \\
\hline
\end{tabular}

Sumber: Kuesioner, diolah, 2021

Tahapan berikutnya adalah melakukan pengujian dengan prosedur bootsraping untuk mengetahui pengaruh antara variabel dependen dan independen sehingga menghasilkan kesimpulan. Hasil uji data pada koefisien jalur dengan menggunakan bootsraping mensyaratkan hasil t statistics harus diatas 1,96 untuk dapat dikatakan memiliki pengaruh signifikan.

Tabel 6 menunjukkan nilai $t$ statistics konflik kepentingan terhadap fraud sebesar 2,234 atau dapat disimpulkan $>1,96$ yang berarti hipotesis diterima atau konflik kepentingan berpengaruh positif terhadap fraud dan memiliki pengaruh signifikan. Nilai $t$ statistics perburuan rente terhadap fraud sebesar 2,687 atau dapat disimpulkan $>1,96$ yang berarti hipotesis diterima atau perburuan rente berpengaruh positif terhadap fraud dan memiliki pengaruh yang signifikan.

Tabel 6 Hasil Perhitungan Bootstrap

\begin{tabular}{lccccc}
\hline & $\begin{array}{c}\text { Original } \\
\text { Sample }\end{array}$ & $\begin{array}{c}\text { Sample } \\
\text { Mean }\end{array}$ & $\begin{array}{c}\text { Std } \\
\text { Deviation }\end{array}$ & $\begin{array}{c}\text { T } \\
\text { Statistics }\end{array}$ & $\begin{array}{c}\text { P } \\
\text { Values }\end{array}$ \\
\hline X1 (Conflict of Interest) -> Y (Fraud) & 0.382 & 0.370 & 0.171 & 2.234 & 0.026 \\
X2 (Rent Seeking) -> Y (Fraud) & 0.457 & 0.497 & 0.170 & 2.687 & 0.007 \\
\hline
\end{tabular}

Sumber: Kuesioner, diolah, 2021

\section{Konflik Kepentingan dalam mendeteksi Indikasi Fraud}

Berdasarkan hasil perhitungan path coefficient diperoleh nilai sample asli sebesar 0,382. Angka tersebut menunjukkan bahwa konflik kepentingan berpengaruh positif terhadap fraud. Semakin banyaknya kasus konflik kepentingan dilakukan maka semakin banyak indikasi terjadinya fraud. Hal ini dapat dilihat dari perhitungan $R$ Square yang menunjukkan bahwa 61,5\% indikasi fraud dipengaruhi oleh konflik kepentingan. Tabel 6 menunjukkan bahwa konflik kepentingan terhadap fraud atau lebih tepatnya kolom $t$ statistics menunjukkan angka 2,234. Angka tersebut menunjukkan nilai yang lebih besar dibandingkan dengan kriteria t-tabel yaitu 2,234 >1,96 dengan p-value 0,026 lebih kecil dari kriteria p-value yang seharusnya 0,026<0,05. Dari sini dapat disimpulkan bahwa variabel konflik kepentingan berpengaruh positif signifikan terhadap fraud. 
Hipotesis ini sejalan dengan penelitian (Oktaviani, Herawati, \& Atmadja, 2017) mengatakan bahwa konflik kepentingan berpengaruh positif terhadap potensi fraud dalam pengelolaan keuangan desa, konflik kepentingan yang dimaksud dalam situasi tersebut adalah ketika seorang yang memiliki wewenang diduga memiliki kepentingan pribadi sehingga mempengaruhi kinerjanya dan berujung pada fraud. Pada penelitian yang dilakukan oleh (Suryandari \& Priyanto, 2012) dijelaskan bahwa semakin tinggi tingkat konflik kepentingan yang terjadi pada suatu perusahaan maka semakin tinggi diterapkannya konservatisme akuntansi dan di dalam penelitian (Zulfa, 2017) dikemukakan bahwa konflik kepentingan memiliki pengaruh positif terhadap konservatisme akuntansi hal ini biasanya disebabkan oleh terjadinya kebijakan dimana investor memilih dan mengatur manajer dalam mentransfer keuntungan dari kekayaan kreditor dan hal ini yang dapat menyebabkan kecurangan terjadi. (Septiningrum, 2017) mengemukakan bahwa konflik kepentingan berpengaruh positif terhadap kesenjangan anggaran dalam penyusunan anggaran partisipatif, penelitian ini selaras dengan teori agensi yang menyebutkan terdapatnya perbedaan kepentingan antara manajer atas dan manajer bawah sehingga menimbulkan kecurangan yang dilakukan oleh satu pihak kepada pihak lain. Dijelaskan oleh (Saputra, Ni, \& Jayawarsa, 2019) bahwa konflik kepentingan memiliki pengaruh positif terhadap independensi auditor dimana konflik kepentingan tidak selalu memberi kerugian secara langsung namun setelah konflik kepentingan tersebut terjadi maka akan ada kerugian yang ditimbulkan, konflik kepentingan juga dilokalisir sebagai perbuatan tidak etis. Sejalan dengan penelitian yang dilakukan oleh (Hermawan \& Novita, 2021) dijelaskan bahwa tata kelola perusahaan memiliki pengaruh positif pada upaya untuk meminimalisirkan indikasi kecurangan yang salah satunya merupakan konflik kepentingan.

Hasil penelitian ini menunjukkan bahwa indikator konflik kepentingan yang didorong oleh personal, relasional, struktural, dan kultural. Sejalan dengan persepsi auditor yang dimana responden menyetujui bahwa konflik kepentingan terjadi karena personal dipengaruhi oleh karakteristik individu, kepribadian, dan emosional. Responden menyetujui bahwa konflik kepentingan terjadi karena keinginan individu itu sendiri maka dari itu untuk meminimalisir konflik kepentingan dalam suatu entitas maka perlu adanya proses penilaian kinerja guna untuk mengetahui jejak rekam dari seseorang yang akan mengisi posisi penting di dalam entitas, perusahaan juga wajib melakukan psikotest untuk calon karyawan dan memberi pelatihan pengembangan emosional dan spiritual untuk karyawan guna memotivasi karyawan dan meningkatkan potensi yang dimilikinya. Relasional dipengaruhi oleh hubungan relasional antar individu, antar kelompok, antar pemangku kepentingan, antar keyakinan, dan sebagainya yang sering juga ditemukan terdapatnya hubungan istimewa antara manajemen dan vendor, terdapatnya kegiatan nepotisme di dalam suatu entitas. Struktural dipengaruhi oleh struktur entitas yang mengatur tentang kode etik dan perilaku bisnis seperti pelarangan menerima pemberian gratis, memiliki auditor internal guna memberi pendapat objektif, dan guna mencegah kepemimpinan management override. Kultural dipengaruhi oleh nilainilai kultur yang ada di dalam suatu entitas yang memberi pengaruh dalam pelaksanaan kegiatan operasinya seperti diharapkan memiliki sebuah sistem seperti whistleblowing dan mengadakan seminar berkala mengenai anti fraud guna mencegah dan menyadari segala bentuk konflik kepentingan yang akan berujung pada fraud. 


\section{Perburuan Rente dalam mendeteksi Indikasi Fraud}

Berdasarkan hasil perhitungan path coefficient diperoleh nilai sample asli sebesar 0,457 . Angka tersebut menunjukkan bahwa perburuan rente berpengaruh positif terhadap fraud. Semakin banyaknya kasus perburuan rente dilakukan maka semakin banyak indikasi terjadinya fraud. Hal ini dapat dilihat dari perhitungan $R$ Square yang menunjukkan bahwa 61,5\% indikasi fraud dipengaruhi oleh perburuan rente. Tabel 6 menunjukkan bahwa konflik kepentingan terhadap fraud atau lebih tepatnya kolom $t$ statistics menunjukkan angka 2,687. Angka tersebut menunjukkan nilai yang lebih besar dibandingkan dengan kriteria t-tabel yaitu 2,687 >1,96 dengan $p$-value 0,007 lebih kecil dari kriteria $p$-value yang seharusnya $0,007<0,05$. Dari sini dapat disimpulkan bahwa variabel perburuan rente berpengaruh positif signifikan terhadap fraud.

Hipotesis ini sejalan penelitian (Nugraha, 2018) menjelaskan bahwa terjadinya kegiatan perburuan rente yang dilakukan antara penyelenggara dengan penyedia dan berujung korupsi (penyuapan, penggelembungan dana, penggelapan anggaran, penyalahgunaan wewenang, dan sebagainya). Penelitian ini juga selaras dengan hasil penelitian yang dilakukan oleh (Nugroho, 2018) yang di dalam penelitiannya menyatakan banyaknya fenomena aktivitas ekonomi perburuan rente dan korupsi. Penelitian (Liu, Lin, Chan, \& Fung, 2018) menyatakan bahwa terdapat pengaruh positif dan signifikan antara pemburu rente dan manajemen laba yang dimana perburuan rente mempengaruhi manajemen laba. (Lee, Ning, Hsieh, \& Lee, 2020) menunjukkan hasil bahwa perusahaan yang terdaftar lebih cenderung melakukan aktivitas perburuan rente daripada perusahaan yang tidak terdaftar, penelitian ini juga melengkapi tentang pengaruh positif koneksi politik terhadap kinerja swasta atau pemburu rente. Penelitian ini sejalan dengan penelitian yang dilakukan oleh (Saleh \& Perdana, 2019) yang melihat adanya bentuk praktik rent seeking yang terjadi pada kasus IUP oleh pemerintah setempat yang mana birokrat berusaha untuk mendapatkan hak mengalokasikan rente yang dihasilkan dari institusi negara untuk kepentingan pribadi. Praktik ini dilakukan dengan cara mengeluarkan izin usaha pertambangan. Dalam penelitian ini melengkapi pengaruh positif perburuan rente terhadap Fraud. (Mahpudin \& Aziz, 2021) mengemukakan bahwa perburuan rente tidak selalu berkaitan dengan mencari keuntungan materi namun bisa dalam bentuk politik balas budi dan memanipulasi kebijakan yang dapat menguntungkan para pemangku kepentingan. Dalam saat yang bersamaan perusahaan mendapatkan keuntungan dari kebijakan yang dibuat oleh elit politik dengan cara menyuap dan cara lain yang melanggar konstitusi.

Hasil penelitian ini menunjukkan bahwa indikator perburuan rente yang terdiri dari working capital rendah, hutang yang tinggi, creative accounting, imunitas rendah, dan good governance yang semu sejalan dengan persepsi auditor yang dimana responden menyetujui bahwa praktik perburuan rente terjadi ketika perusahaan dengan modal kerja dan pengalaman yang minim memenangkan proyek yang bernilai besar. Selanjutnya ketika suatu perusahaan yang mendanai proyeknya dengan kekuatan hutang atau memiliki hutang yang tinggi maka itu bisa menjadi salah satu indikasi perburuan rente. Pelaku praktik perburuan rente melakukan make up pada laporan keuangan seperti melakukan rekayasa agar laporan keuangan terlihat memenuhi regulasi, sesuai dengan standar, dan dapat meyakinkan para pemangku kepentingan. Perilaku perburuan rente dapat terlihat ketika 
terdapatnya perubahan regulasi atau perubahan pejabat publik dan perubahan tersebut bisa memberikan peluang untuk pelaku perburuan rente. Praktik perburuan rente juga dapat terlihat dari situasi saat menghadapi krisis ekonomi. Perusahaan yang terindikasi praktik perburuan rente memiliki tata kelola perusahaan yang hanya dijadikan sebagai suatu pemenuhan syarat dan hanya sebuah formalitas saja.

\section{SIMPULAN}

Berdasarkan hasil pengolahan data serta hasil uji hipotesis yang dilakukan dalam bab sebelumnya variabel konflik kepentingan dan perburuan rente berpengaruh positif dan signifikan terhadap indikasi fraud. Artinya responden setuju jika konflik kepentingan dan kegiatan perburuan yang terjadi di sebuah entitas dan berjalan secara terus menerus maka akan menyebabkan fraud yang dapat merugikan entitas, negara, dan masyarakat secara luas. Maka dari itu kegiatan konflik kepentingan dan perburuan rente perlu disadari dan dicegah agar tidak menimbulkan kerugian yang menyebabkan masalah yang berkelanjutan.

Implikasi penelitian ini didukung oleh Fraud Pentagon Theory. Hasil penelitian yang menunjukkan bahwa konflik kepentingan dan praktik perburuan rente memiliki pengaruh terhadap fraud yang dapat ditemukan pada kelima elemen Fraud Pentagon Theory yaitu pressure, rationalization, opportunity, capability, and arrogance.

\section{PUSTAKA ACUAN}

Akdon, \& Riduwan. (2013). Rumus dan Data dalam Aplikasi Statistika. Bandung: Alfabeta. Alfina, D. F., \& Amrizal. (2020). Pengaruh Faktor Tekanan, Peluang, Rasionalisasi, Kompetensi, dan Arogansi Terhadap Kecurangan Laporan Keuangan . Akuntabilitas: Jurnal Ilmu Akuntansi, 63-76.

Detik News. (2020, December 6). Total Suap Diduga Diterima Juliari Batubara Terkait Bansos Corona Rp 17 M. Jakarta, DKI Jakarta, Indonesia.

Ghozali, I., \& Latan, H. (2015). SmartPLS. In Partial Least Squares Konsep, Teknik dan Aplikasi Menggunakan Program SmartPLS. Semarang: Universitas Diponegoro.

Hermanto, B. (2020). Praktik Rent Seeking dalam Perekonomian Indonesia. Cirebon: Kompasiana.

Hermawan, A., \& Novita. (2021). The Effect of Governance, Risk Management, and Compliance on Efforts to Minimize Potential Fraud Based on the Fraud Pentagon Concept. Asia Pacific Fraud Journal, 82-95.

Lee, C.-C., Ning, S., Hsieh, M.-F., \& Lee, C.-C. (2020). The going-public decision and rentseeking activities: Evidence from Chinese private companies. ELSEVIER Economic Systems, 1-14.

Liputan 6. (2020). Penangkapan Menteri Edhy Prabowo oleh KPK Sakiti Hati Nelayan Kecil. Jakarta: liputan 6.

Liu, B., Lin, Y., Chan, K. C., \& Fung, H.-G. (2018). The dark side of rent-seeking: The impact of rent-seeking on earnings management. ELSEVIER Journal of Business Research, 1-14. 
Mahpudin, \& Aziz, Y. M. (2021). Rent Seeking dan Praktik Korupsi di Tubuh BUMD: Kasus BUMD PT Banten Global Development (BGD). Jurnal Wacana Politik, 1-12.

Mahsun, M. (2020). Pengaruh Praktik Rent Seeking Terhadap Akuntabilitas dan Kredibilitas Laporan Keuangan. Trilogi Auditing Competion and Seminar Vol.2. Jakarta: Trilogi.

Nugraha, R. H. (2018). Analisis Perilaku Rent Seeking dan Korupsi pada Pengelolaan Infrastruktur Pelabuhan di Indonesia Studi Kasus: PT Pelabuhan Indonesia 2. Bogor: Institut Pertanian Bogor.

Nugroho, F. A. (2018). Aktivitas Ekonomi Perburuan Rente dan Korupsi pada Pembangunan Daerah Kabupaten Pandeglang: Perspektif Ekonomi Politik. Bogor: Institut Pertanian Bogor.

Oktaviani, I. A., Herawati, N. T., \& Atmadja, A. T. (2017). Pengaruh Praktik Akuntabilitas, Conflict of Interest dan Penegakan Hukum terhadap Potensi Fraud dalam Pengelolaan Keuangan Desa di Kabupaten Buleleng. e-Journal Universitas Pendidikan Ganesha, 10.

Pratama, W. P. (2020). Waduh, Kerugian Kasus Jiwasraya Lebih dari Rp37 Triliun. Jakarta: Bisnis.com.

Priantara, D. (2016). Mengenali Konflik Kepentingan Sebagai Salah Satu Bentuk Fraud. Jakarta: Warta Ekonomi.

Rozie, F. (2019, Oktober 11). Kasus Suap Pengadaan Mesin dan Pesawat Garuda, KPK Periksa Eks Direktur Teknik. Jakarta, DKI Jakarta, Indonesia.

Saputra, K. A., N. M., \& Jayawarsa, A. A. (2019). Conflict of Interest dan Independensi Auditor pada Kantor Akuntan Publik di Bali. Jurnal InFestas, 1-9.

Sekaran, U., \& Bougie, R. (2017). Metode Penelitian untuk Bisnis Pendekatan PengembanganKeahlian. Jakarta: Salemba Empat.

Septiningrum. (2017). Pengaruh Peserpsi Mahasiswa Mengenai Konflik Kepentingan terhadap Kesenjangan Anggaran dalam Penyusunan Anggaran Partisipatif. Jurnal Profita, 1-11.

Shughart, W. F., Razzolini, L., \& Reksulak, M. (2013). The Elgar Companion to Public Choice, Second Edition. Logan: Edward Elgar.

Sugiyono. (2016). Metode Penelitian Bisnis (Pendekatan Kuantitatif, Kualitatif, dan R\&D). Bandung: Alfabeta.

Sulistiyana, D. B., \& Seran, G. G. (2016). Pengelolaan Konflik Kepentingan. Jakarta: Direktorat Pendidikan dan Pelayanan Masyarakat.

Supriyono, R. (2018). Akuntansi Keprilakuan. Yogyakarta: Gajah Mada University Press.

Suryandari, E., \& Priyanto, R. E. (2012). Pengaruh Resiko Litigasi dan Tingkat Kesulitan Keuangan Perusahaan terhadap Hubungan antara Konflik Kepentingan dan Konservatisme Akuntansi. Jurnal Akuntansi dan Investasi Vol. 12 No. 2, 161-174.

Wahyuni, A. S. (2019). Kritik Teori Keagenan dalam Artikel Akuntansi: Konteks Ke-IndonesiaAn. Jurnal Akuntansi dan Teknologi informasi (JATI), 1-14.

Wongso, A. (2012). Pengaruh Kebijakan Dividen, Struktur Kepemilikan, dan Kebijakan Hutang terhadap Nilai Perusahaan dalam Perspektif Teori Agensi dan Teori Signaling. Widya Mandala, 1-6.

Zulfa, A. (2017). Pengaruh Kesulitan Keuangan, Konflik Kepentingan, Insentif Pajak terhadap Konservatisme Akuntansi dengan Resiko Litigasi sebagai Variabel Moderasi Periode 2012-2014. Semarang: Fakultas Ekonomi UNISSULA. 